\title{
Epäröinnistä venäläisissä televisiokeskusteluissa
}

Hanna Laitinen

Väitöstutkimukseni aiheena on epäröinti ja sen ilmeneminen vuorovaikutuksessa. Tutkin, miten epäröinti ilmenee venäläisissä televisiokeskusteluissa vaikkapa, kun ihminen miettii sopivan ilmauksen valintaa tai suunnittelee tulevaa puheensa sisältöä tai rakennetta.

Puhe on ajassa lineaarisesti askel askeleelta etenevää toimintaa. Se on suunnattu toisille ihmisille, ja se muovautuu yhteistoiminnan tuloksena. Tavallisessa, ennalta valmistelemattomassa tilanteessa puhuja ei yleensä tuota puhettaan sujuvasti, vaan siinä esiintyy aika ajoin epäröintiä. Kuten Wallace Chafe $(1980,171)$ on todennut: ”Joskus ihmiset epäröivät, kun he miettivät, mitä he voisivat sanoa seuraavaksi, ja joskus, kun he miettivät, miten pukea sanoiksi se, mitä he ovat päättäneet sanoa." Ylipäänsä epäröinti on hyvin yleinen ilmiö. On esimerkiksi osoitettu, että noin kuusi prosenttia puheesta on epäröintiä ja se voi ilmetä monella eri tavalla.

Puhujan verbalisointivaikeuksiin voivat olla syynä hänen omat kognitiiviset rajoitteensa tai keskustelukumppanin toiminta. Näin ollen epäröinnin voi luonnehtia olevan kognitiivis-vuorovaikutuksellista. Tämä määritelmä viittaa ilmiön kaksijakoisuuteen: yhtäältä kognitiivisiin prosesseihin ja rajoitteisiin mutta toisaalta myös vuorovaikutuksen tilannesidonnaisuuteen. Kaksijakoisuus näkyy myös siinä, miten tutkimukseni asemoituu suhteessa kielitieteen eri suuntauksiin ja lähitieteenaloihin. Väitöstyöni voidaan sijoittaa muutamien tutkimussuuntauksien leikkauspisteeseen. Toisaalta tutkimukseni nojaa vuorovaikutuksen ainutlaatuisuutta korostaviin ja tilanteista kielenkäyttöä tarkasteleviin tutkimussuuntauksiin, eritoten keskustelunanalyysiin ja vuorovaikutuslingvistiikkaan. Samalla se ottaa paljonkin vaikutteita aloilta, joilla lähdetään liikkeelle puhujasta ja hänen kognitiivisista prosesseistaan, kuten esimerkiksi psykolingvistiikassa tehdään, sekä puhujan halusta ilmaista jotakin merkitystä eli funktionaalisesta lauseopista. 
Väitöstutkimukseni tarkoituksena on kuvata keinot, joilla ihminen epäröi venäläisissä televisiokeskusteluissa, tarkastelemalla epäröintiä funktionaalisen lauseopin näkökulmasta. Lisäksi epäröintiä tarkastellaan etenkin siitä näkökulmasta, miten epäröinnin merkitsimet sijoittuvat suhteessa toimintajaksoihin ja toiminnan etenemiseen.

Tutkimusaineistoni koostuu neljästä keskusteluohjelman katkelmasta. Kaikki ohjelmat on esitetty Venäjän televisiossa. Katkelmien kokonaiskesto on 1 tunti 15 minuuttia, ja aineistossani on yhteensä 17 osanottajaa, jotka edustavat erilaisia sosiaalisia taustoja. Aineistossa on yhteensä noin tuhat epäröinnin merkitsintä, joista osa ilmentää epäröintiä vain potentiaalisesti.

Ennen kuin esittelen epäröinnin ilmenemismuodot, on syytä lyhyesti tarkastella epäröinnin määritelmää. Epäröinnillä tarkoitan puhujan reaktiota tilanteessa, jossa hän ei heti tiedä, miten jatkaa puheenvuoroaan (tai miten aloittaa se). Määritelmästä seuraa, että vuorovaikutukseen liittyvien haasteiden lisäksi ongelma voi liittyä pragmatiikkaan, semantiikkaan, rakenteeseen, sanastoon, fonetiikkaan, itsensä havainnointiin ja itsekorjauksiin.

Tutkimukseni perusteella epäröintiin viittaa seitsemän erilaista merkitsintä, joista melkein jokainen esiintyy melko usein ei ainoastaan indoeurooppalaisissa kielissä mutta myös muissa kielissä, kuten esimerkiksi suomessa ja japanissa [Esimerkit $1 \& 2$ ].

1. Kak eto bylo

$01 \quad \mathrm{~J} / \mathrm{OŠ}: \quad=\mathrm{i}$ čto $\uparrow$ že vsjo-taki?=davaite vspomnim. =ja mitä kuitenkin?=muistellaanpa.

$02 \quad(0.2) \cdot x x($.) vot tot samyi den.

03 (0.2) .hh (.) tuota samaista päivää.

$04>$

NAP-R: $\quad$ hh ja ${ }^{\circ} e^{\circ}$ vyšla na eto pole?

.hh minä ${ }^{\circ} e^{\circ}$ menin sille kentälle?

$05>$

.hh $\mathrm{i}: \rightarrow$ \#ё\# kogda pervye moi\#:\# $e: \#: \rightarrow \# \# e: \rightarrow \#(0.4)$

.hh ja: $\rightarrow$ \#e\# kun ensimmäiset minun\#:\# $e: \#: \rightarrow \# \# e: \rightarrow \#(0.4)$

$06>$

${ }^{\circ} \# m \#^{\circ}$ podruhi po komande. .hh (.) $e$ : \#e\# ${ }^{\circ} \# m: \#^{\circ}$ vystupili

${ }^{\circ} \# m \#^{\circ}$ joukkuetoverini. .hh (.) $e$ : \#e\# ${ }^{\circ} \# m$ :\# $\#^{\circ}$ suoriutuivat

$07>$ neuspeš(no)? (.) .hh i vot tut?=ja načala: \#e: $\rightarrow \#$ (.) tak epäonnises(ti)? (.) .hh ja juuri siinä?=minä aloin: \#e: $\rightarrow \#$ (.) niin

$08>$ $\sim$ skazat $\sim$.hh krutit .hh pljonku v svoih mozgah? a--sanotusti .hh pyörittää .hh nauhaa aivoissani? mutta---

Esimerkki 1 . 


\section{Kak eto bylo}

\begin{tabular}{|c|c|c|}
\hline 01 & VIM: & $\begin{array}{l}=\text { eto že ogrom } \uparrow \text { naja summa. }= \\
=\text { sehän on valtava summa. }=\end{array}$ \\
\hline 02 & NAP-R: & $=\left[{ }^{\circ}(-)^{\circ} \quad\right]$ \\
\hline $03>$ & J/OŠ: & $\begin{array}{l}=\left[\begin{array}{ll}\text { čto } & \text { vot}\end{array}\right] e: \rightarrow \mathrm{ob} \text { po: po povodu progulok } ?= \\
=[\text { mitä } \text { tota }] e: \rightarrow \text { siitä liittyen: liittyen } \text { kävelyretkiin } ?=\end{array}$ \\
\hline $04>$ & & $\begin{array}{l}=[e: \rightarrow \text { gorod posmotret }] \\
=[e: \rightarrow \text { kaupunkia katsomaan? }]\end{array}$ \\
\hline $05>$ & VIM: & $\begin{array}{c}\text { pro]gulok }= \\
\text { käve]lyretkiin. }=\end{array}$ \\
\hline $06>$ & & $\begin{array}{ll}=\text { čto ja } z \text { des } \quad[(-) & \text { skazat } .] » \\
=\text { mitä minä tässä }[(--) & \text { sanoa } .] »\end{array}$ \\
\hline 07 & J/OŠ: & $\begin{array}{l}\text { [možno bylo vyiti }(-)] \\
{[\text { oliko mahdollista mennä ulos }(-)]}\end{array}$ \\
\hline 08 & VIM: & $\begin{array}{l}\text { »bojazn } \uparrow \text { byla.=--- } \\
\text { "pelkoa oli.=--- }\end{array}$ \\
\hline
\end{tabular}

\section{Esimerkki 2.}

Merkitsimet on esitelty seuraavassa taulukossa [Taulukko 1]. Leksikaalisia merkitsimiä on yhteensä kahdeksan. Ne ovat $n u$ (no), vot (tuo/toi, tuota/tota), značit (eli, siis), kak by (ikään kuin, niinku), tak skazat (niin sanotusti, niin sanoakseni), skažem (sanotaan, sanokaamme),

\begin{tabular}{|l|l|}
\hline 1) & $\begin{array}{l}\text { puheeseen liittyvän ongelman eksplikointi kuten esimerkissä } 2 \text { (rivillä 6) čto ja zdes (--) } \\
\text { skazat (mitä minä tässä (--) sanoa) }\end{array}$ \\
\hline 2) & epäröintiäänteet ( e m) \\
\hline 3$)$ & $\begin{array}{l}\text { prosodiset piirteet: äänteen venytys (:), monotoninen intonaatio }(\rightarrow \text { ) sekä nariseva ääni (\# } \\
\text { \#) kuten esimerkissä } 1 \text { (r. 5) } i: \rightarrow \text { (ja: } \rightarrow \text { ) ja moi\#:\# (minun\#:\#) }\end{array}$ \\
\hline 4$)$ & ns. tyhjät tauot kuten esimerkissä 1 (r. 5) (0.4) \\
\hline 5$)$ & $\begin{array}{l}\text { leksikaaliset merkitsimet kuten esimerkissä } 1 \text { (r. 7-8) tak skazat (niin sanotusti) ja esimer- } \\
\text { kissä 2 (r. 3) vot (tota) }\end{array}$ \\
\hline 6$)$ & toistot kuten esimerkissä 2 (r. 3) po po (suhteen suhteen*) \\
\hline 7$)$ & $\begin{array}{l}\text { viivyttely pragmaattisen projektion mukaisessa etenemisessä; esimerkissä } 2 \text { tavataan tällainen } \\
\text { viive, kun vieras kierrättää juontajan sanoja (r. 5) po: povodu progulok (liittyen kävelyretkiin). }\end{array}$ \\
\hline
\end{tabular}

* Käännös on hieman epätarkka. Rakenteen po povodu merkitys on "suhteen". Olen pyrkinyt suomentamaan venäjänkieliset esimerkkikatkelmat siten, että puhujan rakenteelliset valinnat näkyvät mahdollisimman tarkasti suomenkielisissä käännöksissä. Näin ollen käännösvastine ei välttämättä ole kaikista luontevin vaihtoehto.

\section{Taulukko 1. Merkitsimet}


takoi (sellainen) ja etot (tämä). Niistä takoi (sellainen) ja etot (tämä) kongruoivat pääsanansa kanssa, mutta muut eivät taivu. Väitöstutkimuksessani selvisi, että melkein jokaisella epäröinnin merkitsimellä on omat erityispiirteensä. Samoin kaikilla merkitsimillä on rajoituksensa. Tällöin kyseinen kielenaines ei viittaa epäröintiin tai ainakin epäröintifunktio on kiistanalainen. Suurimmat rajoitukset koskevat tyhjiä taukoja ja leksikaalisia merkitsimiä.

Epäröintiä tarkastellaan väitöskirjassani suhteessa vuoroon ja vuoron rakenneyksikköön (VRY). Pääkonteksteja, joissa epäröintiä ilmenee, on siten kolme: vuoronalkuinen epäröinti, vuoron rakenneyksikönalkuinen epäröinti ja keskellä vuoron rakenneyksikköä ilmenevä epäröinti. Kaikilla näillä kolmella epäröintikontekstilla on myös omat alakontekstinsa, joilla on omat tyypilliset sijaintinsa suhteessa toimintajaksoon ja toiminnan etenemiseen. Käsitteiden "vuoro" ja "vuoron rakenneyksikkö" välistä suhdetta voi havainnollistaa seuraavan kuvion avulla [Kuvio 1]. Jos vuoron rakenneyksikkö muodostaa itsenäisen kokonaisuuden toiminnan, syntaksin ja prosodian kannalta, sen voi määritellä vuoroksi.

\begin{tabular}{|l|l|}
\hline Puhuja: & VRY $(+\mathrm{VRY}+\mathrm{VRY}+\mathrm{VRY}+\ldots)=$ vuoro \\
\hline Keskustelukumppani: & VRY $(+\mathrm{VRY}+\mathrm{VRY}+\mathrm{VRY}+\ldots)=$ vuoro \\
\hline
\end{tabular}

Kuvio 1. Vuoro ja vuoron rakenneyksikkö

Tutkimustulosteni perusteella voi sanoa, että vuoronalkuiset epäröinnit liittyvät pitkälti vuorotteluun ja siihen, että aineistoni koostuu nimenomaan televisiokeskusteluista. Kuten muissakin tutkimuksissa on osoitettu, vuoron alussa esiintyy varsin usein epäröintiä. Lisäksi tutkimukset osoittavat, että uuden toiminnon aloittaminen saattaa olla ongelmallista. Aineistossani tämä näkyy erityisesti juontajan vuoroissa, kun hän siirtyy agendalla eteenpäin. Aiemmissa tutkimuksissa on tarkasteltu myös epäröinnin ja vuorottelun välistä suhdetta. Väitöstutkimuksessani tämä näkyy eritoten silloin, kun keskustelijat neuvottelevat, mihin suuntaan toiminta on rakentumassa. Tällaisia neuvottelukonteksteja aineistossani on kolme.

Vuoron rakenneyksikönalkuinen epäröinti liittyy vuorostaan siihen, että puhujan vuoro on edennyt sellaiseen vaiheeseen, jossa se projisoi pitkää, usein moniyksikköistä vuoroa. Tähän epäröintikontekstiin liittyvät tutkimustulokseni ovat hyvin samankaltaisia muiden tutkimusten kanssa. Esimerkiksi jo varsin varhaisissa epäröintitutkimuksissa on havaittu, että epäröintiä esiintyy usein, kun lausuma on vasta alkuvaiheessa. Samaten jo vuosikymmeniä sitten on pantu merkille, että kaikenlaiset siirtymät puheessa ovat tyypillisiä paikkoja epäröinnille. Nämä kaksi ilmiötä voi havaita myös aineistostani. Lisäksi tutkimukseni osoittaa, että hyvin pienetkin siirtymät toiminnan etenemisessä ovat tyypillisiä epäröintiä aiheuttavia tilanteita. Tällaisia pieniä siirtymiä ovat mm. könttien (chunks) väliset siirtymät sekä kolme esiintymiskontekstia, joissa taustoituksesta siirrytään etualalle.

Kuten muissakin tutkimuksissa on osoitettu, vuoron rakenneyksikön keskellä oleva epäröinti näyttää liittyvän pääsääntöisesti puheentuotannon viimeisiin vaiheisiin, kuten esimerkiksi leksikaalisiin valintoihin, artikuloinnin ongelmiin ja virheellisten tuotosten korjaamiseen. Muihin tutkimustuloksiin tukeutuen sekä ottaen huomioon yleisen käsityksen maailmasta jaoin leksikaaliset sanahaut kolmeen kategoriaan. Ne ovat ongelma käsitteellistämisessä, ongelma yksityiskohdan muistamisessa ja ongelma sanan tai ilmauksen valinnassa. 


\begin{tabular}{|l|l|l|l|}
\hline \multicolumn{1}{|c|}{$\begin{array}{c}\text { Epäröinnin } \\
\text { merkitsimien sijainti }\end{array}$} & \multicolumn{1}{|c|}{ Vuoron alussa } & \multicolumn{1}{|c|}{$\begin{array}{l}\text { Vuoron rakenne- } \\
\text { yksikön alussa }\end{array}$} & \multicolumn{1}{|c|}{$\begin{array}{c}\text { Keskellä vuoron } \\
\text { rakenneyksikköä }\end{array}$} \\
\hline Eksplikointi & tietyissä konteksteissa & - & tietyissä konteksteissa \\
\hline Epäröintiäänteet & $\begin{array}{l}\text { kaiken tyyppisissä on- } \\
\text { gelmissa }\end{array}$ & $\begin{array}{l}\text { kaiken tyyppisissä on- } \\
\text { gelmissa }\end{array}$ & $\begin{array}{l}\text { kaiken tyyppisissä on- } \\
\text { gelmissa }\end{array}$ \\
\hline Prosodiset piirteet & $\begin{array}{l}\text { kaiken tyyppisissä on- } \\
\text { gelmissa }\end{array}$ & $\begin{array}{l}\text { kaiken tyyppisissä on- } \\
\text { gelmissa }\end{array}$ & $\begin{array}{l}\text { kaiken tyyppisissä on- } \\
\text { gelmissa }\end{array}$ \\
\hline Tyhjät tauot & $\begin{array}{l}\text { kaiken tyyppisissä on- } \\
\text { gelmissa }\end{array}$ & $\begin{array}{l}\text { ei-syntaksiset, pitkät, } \\
\text { ketjuissa esiintyvät }\end{array}$ & $\begin{array}{l}\text { kaiken tyyppisissä on- } \\
\text { gelmissa }\end{array}$ \\
\hline $\begin{array}{l}\text { Leksikaaliset merkit- } \\
\text { simet }\end{array}$ & $\begin{array}{l}\text { tietyt kongruoimatto- } \\
\text { mat, ketjuissa esiin- } \\
\text { tyvät }\end{array}$ & $\begin{array}{l}\text { tietyt kongruoimatto- } \\
\text { mat, ketjuissa esiin- } \\
\text { tyvät }\end{array}$ & $\begin{array}{l}\text { tietyissä konteksteissa, } \\
\text { ketjuissa esiintyvät }\end{array}$ \\
\hline Toistot & melko harvoin & $\begin{array}{l}\text { melkein kaiken tyyppi- } \\
\text { sissä ongelmissa }\end{array}$ & tietyissä konteksteissa \\
\hline $\begin{array}{l}\text { Viivyttely pragmaatti- } \\
\text { sen projektion mukai- } \\
\text { sessa etenemisessä }\end{array}$ & monen tyyppisissä on- \\
gelmissa & - & $\begin{array}{l}\text { erityisesti yksityiskoh- } \\
\text { dan muistamiseen liit- } \\
\text { tyvissä ongelmissa }\end{array}$ \\
\hline
\end{tabular}

Taulukko 2. Epäröinnin merkitsimien tyypillinen sijainti suhteessa vuoroon ja vuoron rakenneyksikköön

Kun tarkastellaan, miten epäröinnin merkitsimet sijoittuvat suhteessa esitettyihin alakonteksteihin, voidaan vetää johtopäätöksiä siitä, missä konteksteissa mikäkin merkitsin voi esiintyä. Epäröintiäänteitä ja prosodisia piirteitä löytyy jokaisesta kontekstista. Niitä voikin luonnehtia geneerisiksi epäröinnin merkitsimiksi. Kaikissa konteksteissa esiintyy myös epäröintiketjuja, vaikka tietyissä konteksteissa ne ovatkin erittäin lyhyitä. Tämä johtunee siitä, että ongelma ei ole kovin vakava. Varsin laajasti käytetään myös toistoja ja tyhjiä taukoja. Sitä vastoin eksplikointia ja viivyttelyä pragmaattisen projektion mukaisessa etenemisessä sekä leksikaalisia merkitsimiä, erityisesti sellaisia, jotka kongruoivat pääsanansa kanssa, käytetään harvemmin, ja niiden esiintymiskonteksti on harvalukuisempi. Näillä kolmella epäröinnin merkitsimellä on myös selvimmät erityispiirteensä. Eksplikointia ja viivyttelyä pragmaattisen projektion mukaisessa etenemisessä käytetään etenkin silloin, kun puhujalla on verrattain suuria ongelmia, esimerkiksi semanttisia.

Leksikaalisten merkitsimien käyttö liittyy aineistoni perusteella hyvin vahvasti jokaisen merkitsimen leksikaaliseen merkitykseen. Keskellä vuoron rakenneyksikköä leksikaaliset merkitsimet implikoivat varsin tarkasti, millainen ongelma on kyseessä sekä miten puhuja suhtautuu ongelmaan ja sen ratkaisemiseen. Tämän lisäksi leksikaalisten merkitsimien käytöstä voi havaita muutamia säännönmukaisuuksia. Esimerkiksi, kun kyseessä on käsitteellistämiseen liittyvä ongelma, leksikaalinen merkitsin, jolla siihen viitataan, implikoi usein epätarkkuutta. Kun kyseessä onkin sanan tai ilmauksen valitsemiseen liittyvä ongelma, sanahaussa käytetään varsin usein leksikaalista merkitsintä, joka ennemminkin viittaa tarkkuuteen.

Johtopäätöksenä voidaan todeta, että televisiokeskustelujen osanottajat tunnistavat varsin hyvin, mikä heille aiheuttaa ongelmia, mitkä sanat, yksityiskohdat ja käsitteet ovat heille tuttuja ja nopeasti löydettävissä muistista eli millaisia ongelmia on helppo ratkaista ja samaten, minkä tyyppiset ongelmat ovat monimutkaisempia. Voidaan myös päätellä, että 
puhujien käsitykset siitä, millaisia merkitsimiä voi käyttää missäkin epäröintitilanteessa, ovat varsin yhtenevät.

Mikä sitten on väitöstutkimukseni anti? Sen lisäksi, että tutkimukseni laajentaa ymmärrystä ilmiön moninaisuudesta, tuloksia voi hyödyntää venäjän kielen opetuksessa etenkin kun venäjää opetetaan vieraana kielenä. Tutkimustulokseni voivat olla hyödyllisiä myös retoriikasta kiinnostuneille sekä journalistiikan opiskelijoille.

Venäjänkielisen lektion suomennos on tekijän.

\section{Lähde}

Chafe, Wallace L. (1980), Some reasons for hesitating. - Temporal variables in speech. Studies in honour of Frieda Goldman-Eisler. Ed. Hans W. Dechert \& Manfred Raupach. The Hague: Mouton, 169-180. https://doi.org/10.1515/9783110816570.

FM Hanna Laitisen venäjän kielen alaan kuuluva väitöskirja Projavlenije hezitatsii v besedah na rossijskom televidenii (Epäröinnin ilmeneminen venäläisissä televisiokeskusteluissa) tarkastettiin lauantaina 22.8.2020 Helsingin yliopiston humanistisessa tiedekunnassa. Vastaväittäjänä toimi professori Vera Isaakovna Podlesskaja Moskovan humanistisesta yliopistosta ja kustoksena professori Johanna Viimaranta Helsingin yliopistosta. 